DOI: https://doi.org/10.31392/NZ-npu-143.2019.15

УДК 37.018

ORCID 0000-0001-7628-3543

Мацейків T. I.

\title{
ЕКСПЕРИМЕНТАЛЬНЕ ДОСЛІДЖЕННЯ ПРОБЛЕМИ ФОРМУВАННЯ ГРОМАДЯНСЬКОЇ КОМПЕТЕНТНОСТІ
}

Прочес розробки фундаментальних основ парадигми освіти, орієнтованих на формування громадянської компетентності демократичної української держави, розпочався в Україні у першій половині 90-х років. Стратегічне завдання украӥнської освіти - виховання в особистості любові до Батьківщини, усвідомлення нею свого громадянського обов'язку на основі національних та загальнолюдських цінностей, утвердження якостей громадянина - патріота Украӥни визначено низкою керівних документів, щзо врегульовують освітню галузь $i$ зокрема історичну.

У статті розкрито проблему формування громадянської компетентності старшокласників на уроках історії України. Розглянуто поняття “громадянська компетентність" як інтегративну якість особистості, сукупність знань, умінь, навичок, переживань, емоційно-ціннісних орієнтацій, переконань, які допомагають особистості усвідомити своє місие в суспільстві, успішно реалізуватися як громадянина держави. Значна роль у формуванні громадянської компетентності належить стариій школі, яка розширює знання учнів про прочеси та явища суспільного життя, права людини, основи життя суспільства, сприяє формуванню громадянської позиції людини, ї̈ изіннісних орієнтацій.

Теоретично обгрунтовано та експериментально перевірено методичну модель формування громадянської компетентності старшокласників у прочесі навчання історії Украӥни. Ї̈ сутність полягає у внесенні змін у зміст навчання, запровадженні інноваційних форм $і$ методів проведення занять з одночасною організацією творчої діяльності стариокласників та продуктивної взаємодії учителів та учнів. Формувальним етапом експерименту підтверджено ефективність впровадження методичної моделі в процес навчання історії України в старшій школі.

Ключові слова: громадянська компетентність, навчання вітчизняній історії, психологічний механізм, методика формування громадянської компетентності.

Процес розробки фундаментальних основ парадигми освіти, орієнтованих на формування громадянської компетентності демократичної української держави, розпочався в Україні у першій половині 90-х років. Стратегічне завдання української освіти - виховання в особистості любові до Батьківщини, усвідомлення нею свого громадянського обов'язку на основі національних та загальнолюдських цінностей, утвердження якостей громадянина - патріота України визначено низкою керівних документів, що врегульовують освітню галузь і зокрема історичну.

В умовах незалежної України розпочалася активна розробка питань виховання громадянина вченими - педагогами $[2,4,5,6]$. Серед них існує два основних підходи: 1) виховання громадянина пов'язано насамперед з питанням національної самоідентифікації та вихованням патріотизму; 2) виховання громадянина передбачає формування особистості, якій притаманні громадянська 
свідомість, громадянська ерудиція, громадянські почуття, громадянська поведінка. Основними завданнями виховання громадянина, які відзначаються у працях сучасних педагогів [3, 5], є формування у людини таких рис: патріотизм, національна свідомість і самоідентифікація, гуманізм, що ґрунтується на національних та загальнолюдських цінностях, моральна свідомість, культура поведінки та культура міжетнічних відносин, мотивація до праці тощо.

Педагогічні принципи формування громадянської компетентності обґрунтовані в працях О. Сухомлинської, І. Тараненко, К. Чорної та ін. Психологопедагогічні аспекти фрормування громадянської компетентності учнів розроблені українськими вченими І. Бехом, М. Боришевським, О. Вишневським, П. Ігнатенком, Н. Косарєвою Л. Крицькою, В. Поплужним, І. Тисячник та ін. У працях цих та інших дослідників описано когнітивний, аксіологічний зміст громадянської компетентності, розглянуто процесуальний бік її фрормування, визначені специфічні навчально-виховні завдання, відповідні форми і методи діяльності учнів.

Психологічні і педагогічні підходи до фрормування системи духовних цінностей, ціннісних орієнтацій, ставлень, особистісних якостей та інших загальнопсихологічних і вікових закономірностей розвитку учнів старшої школи висвітлюють в своїх роботах дослідники громадянськості І. Бех М. Боришевський, Л. Крицька, Н. Косарєва, В. Поплужний, П. Ігнатенко, Ю. Олексін та ін.

Особливо важливими є праці з методики навчання історії, що досліджують методологію процесу навчання історії, питання змісту та організації історичної освіти, різні аспекти громадянської освіти (К. Баханов, А. Булда, П. Вербицька, Ю. Завалевський Т. Ладиченко, Ю. Олексін, О. Пометун, М. Рудь, Т. Смагіна, М. Шимановський та ін.).

Mema cmammi - проаналізувати результати педагогічного експерименту 3 формування громадянської компетентності старшокласників у процесі навчання історії України.

Під поняттям “громадянська компетентність” розуміємо інтегративну якість особистості, сукупність знань, умінь, навичок, переживань, емоційно-ціннісних орієнтацій, переконань, які допомагають особистості усвідомити своє місце в суспільстві, успішно реалізуватися як громадянина держави. Громадянська компетентність формується у навчальному процесі засобами різних предметів і виховних впливів, здійснюваних вчителями та класним керівником. У структурі громадянської компетентності, як і кожної ключової, виокремлюють такі компоненти: когнітивний - певну сукупність громадянознавчих знань; ціннісний наявність в учня ціннісних орієнтацій, які визначають громадянські цільові установки, ставлення, позицію особистості; діяльнісно-процесуальний - систему умінь і навичок, що створюють можливість для ефективного функціонування і самореалізації людини в соціумі та демократичній державі.

Значна роль у фрормуванні громадянської компетентності належить старшій школі, яка розширює знання учнів про процес та явища суспільного життя, права людини, основи життя суспільства, сприяє фрормуванню громадянської компетентності людини, їі суспільно-політичних орієнтацій. На цьому ступені формується готовність захищати свої права, права інших людей, будувати індивідуальну й колективну діяльність. 
Спрямованість освіти на фрормування особистості, зокрема на громадянську компетентність учня, потребує суттєвих змін як у змісті, так і у формах навчання історії. Зокрема зміст історичної освіти має забезпечити ефрективне фоормування громадянської компетентності через інформаційний компонент історичного змісту, через відповідні методи, форми, технології навчання, а також за умови, якщо емоційно-оцінювальна діяльність пронизуватиме всі елементи навчання й безпосередньо передбачена у результатах навчання.

Завдання суспільствознавчої освіти згідно з Державним стандартом "полягає у створенні умов для свідомої орієнтації учнів у сучасному світі, суспільстві, формування у них відповідної активної соціальної та громадянської позиції,, підвищення рівня духовної культури школярів, культури спілкування і діяльності, для сприяння їх соціалізації, активної участі в соціально-політичному та економічному житті суспільства, свідомому вибору та підготовці до майбутньої професійної діяльності [1]. Цю мету конкретизовано у завданнях галузі для старшої школи, які передбачають: виховання в учнів толерантного ставлення та поваги до інших народів, правової свідомості, економічного мислення; формування в учнів почуття власної гідності, відповідальності, особистого ставлення до подій та явищ суспільного життя, здатності мати власну активну життєву позицію, робити свідомий вибір, визначати особисті цілі, спрямовані на розвиток суспільства, держави, забезпечення власного добробуту, своєї родини; виховання в учнів рис патріота України, виховання активного, компетентного громадянина; створення умов для свідомої орієнтації в сучасному світі, суспільстві, фрормування в них активної соціальної та громадянської позиції; сприяння участі школярів у соціально-політичному та економічному житті суспільства; підготовка учнів до майбутньої профресійної діяльності [1].

Стандартом передбачений зміст історичної освіти і відповідні результати його засвоєння, що досягаються в курсі історії України в старших класах. Зокрема названі такі елементи навчального матеріалу: “Протистояння демократії $\mathrm{i}$ тоталітаризму. Українська революція початку XX століття. Здобуття Україною державної незалежності. Україна за тоталітарного режиму. Україна у Другій світовій війні. Втрати та героїзм українського народу в Другій світовій війні. Післявоєнна відбудова та розвиток України. Соціальний, політичний та економічний розвиток країн світу в другій половині XX та на початку XXI століть. Розвиток культури. Сучасність. Україна в умовах незалежності. Науково-технічний прогрес. Постіндустріальне суспільство. Зростання ролі освіти і знань. Цінності та якості, притаманні громадянинові демократичного суспільства. Україна та інтеграційні процеси в Європі, місце й перспективи України в глобалізованому світі" [1].

У діючих програмах з історії України (10-11клас) цей зміст вивчається у наступних темах у 10 класах: 1. Україна в Першій світовій війні. 2. Початок Української революції. 3. Розгортання Української революції. Боротьба за відновлення державності; 4. Встановлення й утвердження комуністичного тоталітарного режиму в Україні. 5. Західноукраїнські землі в міжвоєнний період. 6. Україна в роки Другої світової війни; в 11-му класі: 1. Україна в перші повоєнні роки. 2. Україна в умовах десталінізації. 3. Україна в період загострення кризи радянської системи. 4. Відновлення незалежності України. 5. Становлення 
України як незалежної держави. 6. Творення нової України.

Констатуючі дослідження свідчать, що після 1991 року внесено певні, і досить суттєві зміни у навчальні програми з історії. Здійснено спробу створити нову ідеологію вітчизняного суспільствознавства взагалі та шкільної історичної освіти зокрема, уведені в обіг нові фракти і, відповідно, нові інтерпретації. Програми 3 історії, які були прийняті протягом 1991-2001рр. поступово гуманізували навчальний зміст. У пояснювальних записках наголошувалося на прагненні поставити людину в центр історії, остання стала розглядатися - "як драма людських відносин". Змінювалися методологічні засади структурування навчального змісту. Від намагань замінити формаційний підхід до вивчення історичних явищ на цивілізаційний, заснований на пріоритеті загальнолюдських цінностей над класовими, до відмови від будь-яких методологічних концепцій під гаслами дотримання принципу плюралізму. Специфічними, найбільш актуальними на даному етапі розвитку українського суспільства завданнями шкільної історичної освіти були визнані усвідомлення учнями необхідності державотворчих процесів у поєднанні з розбудовою громадянського суспільства, формування в молодого покоління почуття патріотизму, відданості Батьківщині й водночас відчуття приналежності до європейської та світової спільноти.

Зміст шкільної програми з історії, виходячи зі завдань, поставлених у Державному стандарті, поступово було спрямовано на створення оптимальних психолого-педагогічних умов для інтелектуального розвитку, саморозвитку та становлення особистості учня як суб'єкта історичного процесу та суспільних відносин, громадянина-патріота, який керується в своїй діяльності ( життєвому шляху) загальноприйнятими громадянськими соціокультурними нормами та цінностями.

Саме такі тенденції можна спостерігати і в розвитку вітчизняного підручникотворення за останні десятиліття. Рисами підручників з історії, що зорієнтовані на формування громадянської компетентності старшокласників, стали: оптимальне співвідношення між політичною, економічною, соціальною історією і духовною історією (що постає як процес пошуку національних, загальнолюдських, демократичних громадянських цінностей) в історичному змісті, як в текстовому компоненті підручника, так і в джерельній базі; поліконцептуальний характер викладу змісту, висвітлення місця пересічної людини в політичній, економічній, соціальній та культурній історії, наявність громадянознавчого контексту у дидактичній концепції підручника, забезпеченість необхідними навчальними текстами та різноманітними, зокрема, контроверсійними історичними джерелами, що висвітлюють діяльність різних політичних сил, життя суспільних груп, видатних постатей та пересічної людини, наявність у тексті історичних джерел громадянознавчого змісту, тощо.

В процесі констатувального експерименту досліджувався стан сорормованості громадянської компетентності у старшокласників за існуючої масової практики навчання. Аналіз отриманих даних свідчить, що фрормування громадянської компетентності посідає поки що недостатнє місце у навчальному процесі ЗН3. Значна частина вчителів недостатньо обізнана з тим, у чому полягає сутність громадянської компетентності учнів як окремого завдання історичної освіти. Мало уваги приділяється інноваційним організаційним формам навчальних 
занять, впровадження яких створює умови для фрормування активної особистості, громадянина, розвитку критичного мислення, толерантного ставлення до інших. Одним з важливих завдань, яке необхідно вирішувати на державному рівні, $\epsilon$ також забезпечення впливу змісту підручників з історії на громадянські почуття й цінності учнів.

Результати констатувального етапу дослідження показали, що в діяльності навчальних закладів 3 формування громадянської компетентності старшокласників у процесі навчання історії наявні певні недоліки, зокрема:

1) не простежується чітко науково обґрунтована система цієї роботи;

2) не завжди скоординовані дії вчителів різних предметів, спрямованих на формування громадянської компетентності учнів;

3) не системно застосовуються пізнавальні, проблемні та аналітичні завдання, спрямовані на вирішення завдань фрормування громадянської компетентності учнів;

4) методичними об'єднаннями вчителів історії не переглядається зміст дисциплін, у зв'язку з чим тематика та склад навчального матеріалу уроків часто не відповідають потребам фрормування громадянської компетентності. Прямолінійне трактування відповідних проблем, що виносяться на обговорення, їх поверхневе висвітлення не сприяють розвиткові особистості учнів;

5) повільно впроваджуються сучасні інтерактивні методи та технології навчання, в своїй більшості вчителі дотримуються традиційних репродуктивнопояснювальних підходів. Окремі вчителі не завжди володіють науково обґрунтованими та дієвими формами й методами роботи, що сприяють формуванню громадянської компетентності старшокласників. Нудні, одноманітні заняття, позбавлені можливості створення емоційно-оцінюючих ситуацій, призводять до втрати учнями мотивації до навчання історії. У навчальному процесі дотепер переважають екстенсивні форми та методи викладання, метою яких $\epsilon$ розширення обсягу знань, що призводить до інформаційного перевантаження учнів і не дає можливостей для розвитку критичного мислення. Шаблон у формах та методах навчання, формалізм при оцінці результатів навчальної та виховної діяльності знижують якість освіти;

6) на уроках інколи панує суха формальна атмосфрера, що не дає змоги розкритися, бути щирим, не боятися помилитися при виборі рішення. Постійні повчання з боку вчителя, його втручання в хід обговорення, обсмикування, нетактовне виправлення огріхів у відповідях та репліках учнів знижують ефрективність виховного процесу на уроках історії;

7) на уроках часто вивчається переважно зовнішні характеристики подій і явищ, фрактологічний матеріал.

Ці негативні чинники обумовлюють переважно низький рівень сформованості громадянської компетентності значної частини старшокласників і підтверджують необхідність розробки цілісної моделі навчання для втілення її навчальновиховний процес загальноосвітніх навчальних закладів України.

Методика формування громадянської компетентності старшокласників на уроках історії України передбачала, посилення у змісті навчання ролі громадянознавчих знань та системне оволодіння ними старшокласниками, приділення вчителями уваги формуванню громадянських умінь учнів як окремого 
завдання навчального процесу, обов'язкове систематичне застосування інтерактивних технологій навчання, що максимально активізували позицію учня у навчанні. Така побудова методики експериментального навчання давали повністю забезпечити сформульованих мети і завдань фрормування громадянської компетентності старшокласників у навчанні вітчизняної історії .

Експериментальне навчання було побудоване з урахуванням методичних умов фрормування громадянської компетентності старшокласників: орієнтування результатів навчання на цілеспрямоване формування основних складників громадянської компетентності; внесення у навчальний зміст курсу історії України сюжетів, які забезпечують фрормування в учнів громадянознавчих знань, способів діяльності, цінностей, ставлень,організація навчального процесу, що забезпечує постійну активну позицію учнів у навчанні. Вони реалізовувались у змісті експериментальних уроків та технологіях організації процесу навчання учнів вітчизняної історії.

Одним 3 важливих напрямків роботи 3 фрормування громадянської компетентності стало поглиблення громадянознавчих знань учнів старших класів, що містяться в історичних курсах, вміле застосування отриманих знань в практиці навчання. Особливо велике значення має планове та систематичне накопичення старшокласниками понять та розумінь про сутність суспільних відносин, політичні та соціальні процеси, громадянські й суспільні рухи, про значення громадянських цінностей і загальноприйнятих норм поведінки людини і груп людей у складних суспільно-політичних умовах.

Важливий напрям всієї навчальної роботи з учнями старших класів на уроках історії полягає в тому, щоб вимоги фрормування громадянської компетентності, відповідних норм поведінки були втілені в громадянські навички та вміння, моделі поведінки кожного старшокласника, при цьому головним завданням $є$ постійний розвиток навичок громадянської поведінки та перетворення їх у звичку, стійку рису характеру, щоб така поведінка стала внутрішньою потребою старшокласника. Розвиток емоційно-ціннісних ставлень, умінь, навичок громадянської поведінки у старшокласників на уроках історії України шляхом цілеспрямованого педагогічного впливу передбачає застосування комплексу інтерактивних методів і засобів навчальної роботи, зокрема тих, що дають змогу реалізувати у процесі навчання визначені умови ефективного фрормування громадянської компетентності старшокласників. Процес накопичення громадянських навичок та вмінь здійснюється двома основними шляхами: у процесі засвоєння учнями відповідних знань про способи діяльності й їхнього систематичного застосування та спілкування учня 3 однолітками під час використання вчителем інтерактивних технологій та планомірно керованим, шляхом спеціального педагогічного впливу під час навчання.

Побудоване на цих основах експериментальне навчання показало значні зрушення у формуванні громадянської компетентності учнів експериментальних класів. Так кількість учнів, які знаходилися на низькому рівні зменшилася на $22,5 \%$. Водночас збільшилась кількість учнів, які знаходилися на середньому та високому рівнях - відповідно на 10,8\% та 11,7\%. Водночас відповідні показники у контрольних класах майже не зменшилась: кількість учнів, які знаходились на низькому рівні в контрольних класах зменшилась на 2\%., збільшилась кількість 
учнів, які знаходились на середньому та високому рівнях: в контрольних класах відповідно на 0,7\% та 1,7\%. Це дає змогу стверджувати, що відсутність в цих класах цілеспрямованої діяльності, орієнтованої на фрормування громадянської компетентності, не може забезпечити їхнього ефективного розвитку.

Отже, можна зробити висновок про те, що значна роль у формуванні громадянської компетентності належить старшій школі, яка розширює знання учнів про процеси та явища суспільного життя, права людини, основи життя суспільства, сприяє фрормуванню громадянської позиції людини, її ціннісних орієнтацій. Методична модель фрормування громадянської компетентності старшокласників у процесі навчання історії України передбачає внесення певних змін у зміст навчання, запровадження інноваційних форм і методів проведення занять з одночасною організацією творчої діяльності старшокласників та продуктивної взаємодії учителів та учнів. Формувальним етапом експерименту підтверджено ефективність впровадження методичної моделі в процес навчання історії України в старшій школі.

\section{Використана література:}

1. Державний стандарт базової і повної загальної середньої освіти [Елекстронний ресурс]. Режим доступу : http://mon. gov.ua/content/Ocвіта /post-derzh-stan-(1).pdf

2. Баханов К. О. Навчання історії в школі: інноваційні аспекти : посібник. Харків : Основа. 2005. $128 \mathrm{c}$.

3. Побєдаш І. В. Методичні аспекти формування громадянської компетентності учнів основної школи у процесі навчання історії. Науковий вісник Миколаївського начіонального університету. Сер.: Педагогічні науки. Миколаїв, 2016. № 3 (54). С. 268-273.

4. Позняк С. I. Уявлення школярів про громадянина i формування в них громадянської компетентності. Педагогіка і психологія. 2007. № 4. С.83-93.

5. Пометун О. I. Міжпредметний підхід до формування громадянської компетентності старшокласників. Педагогічна $і$ психологічна науки в Україні. Т. 2. Дидактика, методика, інформаційні технології. Київ : Педагогічна думка, 2007. С. 107-117.

6. Тараненко І. Громадянська освіта в Україні: стан та перспективи розвитку. Iсторія в школах України. 2000. № 3. С. 15-18.

\section{References:}

[1] Derzhavnyi standart bazovoi i povnoi zagalnoi serednyoi osvity [Elektronnyi resurs]. Rezhym dostupu : http://mon. gov.ua/content/Oсвіта /post-derzh-stan-(1).pdf

[2] Bahanov K. O. (2005). Navchannia istorii v shkoli: innovatsiyni aspekty : posibnyk. Kharkiv: Osnova. $128 \mathrm{p}$.

[3] Pobiedash I. V. (2016). Metodychni aspekty formuvannia gromadianskoi kompetentnosti uchniv osnovnoi shkoly u protsesi navchannia istorii. Naukovyi visnyk Mykolaivskoho natsionalnoho universytetu. Ser.: Pedahohichni nauky. Mykolaiv, № 3 (54). P. 268-273.

[4] Poznyak S. I. (2007). Uyavlennia shkoliariv pro hromadianyna i formuvannia $v$ nyh hromadianskoi kompetentnosti. Pedahohika i psykhologia. № 4. P. 83-93.

[5] Pometun O. I. (2007). Mizhpredmentnyi pidhid do formuvannia hromadianskoi kompetentnosti starshoklasnykiv. Pedahohichna $i$ psykhologichna nauky $v$ Ukraini. T. 2. Dydaktyka, metodyka, informatsiini tekhnologii. Kyiv : Pedahohichna dumka, P. 107-117.

[6] Taranenko I. (2000). Hromadianska osvita v Ukraini: stan ta perspektyvy rozvytku. Istoriya $v$ shkolah Ukrainy. № 3. P. 15-18. 


\section{МАЦЕЙкИв Т. И. Экспериментальное исследование проблемы формирования гражљанской компетентности. \\ Прочесс разработки фундаментальных основ парадигмь образования, ориентированных} на формирование гражданской компетентности демократического украинского государства, начался в Украине в первой половине 90-х годов. Стратегическая задача украинского образования - воспитание в личности любви к Родины, осознание ею своего гражданского долга на основе национальных и общечеловеческих иченностей, утверждение качеств гражданина - патриота Украины определено рядом руководящих документов, которые регулируют образовательную область и в частности историческую.

$B$ статье исследуется проблема формирования гражданской компетентности старшекласников на уроках истории Украины. Рассмотрено понятие “гражданская компетентность" как интегративное качество личности, совокупность знаний, умений, привычек, переживаний, эмочионально-ценностных ориентаций, убеждений, которые помогают личности осознать свое место в обществе, успешно реализоваться как гражданину государства. Значительная роль в формировании гражданской компетентности принадлежит старшей школе, которая расширяет знания учеников о прочессах и явлениях общественной жизни, правах человека, основах жизни общества, способствует формированию гражданской позиции человека, его иенностных ориентаций.

Осуществлен анализ подходов ученых-методистов $\kappa$ проблеме и ее современной реализачии в условиях реформирования системь образования в иелом и исторического образования в частности характеризуются возможности массовой практики обучения истории Украины в формировании гражданской компетентности старшекласников, освящена методика формирования гражданской компетентности старшекласников на уроках отечественной истории, раскрыт ход и результать экспериментального обучения, анализ соответствующих возможностей учебных програм и учебников по истории.

Ключевые слова: компетентность, гражданская компетентность, методика формирования гражданской компетентности.

MATSEYKIV T. I. Experimental study of the problem of formation of civic competence.

The process of developing the fundamental foundations of the educational paradigm focused on building the civic competence of a democratic Ukrainian state began in Ukraine in the first half of the 1990s. The strategic task of Ukrainian education is to nurture a person's love for the Motherland, to become aware of its civic duty on the basis of national and universal values, to affirm the qualities of a citizen - patriot of Ukraine, defined by a number of governing documents that regulate the educational sector, and in particular the historical one.

The article deals with the problem of formation of civic competence of senior pupils at Ukrainian history lessons. The concept of "civil competence" as an integrative quality of the personality, a set of knowledge, abilities, skills, experiences, emotional and value orientations, beliefs that help the individual to realize their place in society, successfully realized as a citizen of the state are considered. A significant role in the formation of civic competence belongs to the senior school, which expands the students' knowledge about the processes and phenomena of public life, human rights, the foundations of society, contributes to the formation of human civic position, its values.

The methodical model of forming the civic competence of senior pupils in the process of teaching the history of Ukraine is theoretically substantiated and experimentally verified. Its essence is the changes made to the content of the training; introduction of innovative forms and methods of conducting classes with the simultaneous organization of creative activity of senior pupils and productive interaction of teachers and students. The formative stage of the experiment confirmed the effectiveness of the implementation of the methodical model in the process of teaching the history of Ukraine in the senior school.

Keywords: competence, civic competence of personality, formation of civic competence, personality methodical conditions, teaching native history. 